\title{
A Below-Knee Becker Nevus: An Unusual Presentation
}

\section{Diz Altı Beker Nevüs: Nadir Bir Prezentasyon}

Hakan Turan ${ }^{1}$, Esma Uslu ${ }^{1}$, Emrah Gün ${ }^{2}$

${ }^{1}$ Düzce Üniversitesi Tıp Fakültesi, Dermatoloji Anabilim Dalı

${ }^{2}$ Düzce Üniversitesi Tıp Fakültesi, Pediatri Anabilim Dalı

Dear Editor;

Becker nevus (BN) is a unilateral cutaneous hamartoma characterized by well-defined, hyperpigmented patches with a geographic configuration and covered less or more by terminal hairs. It is first defined by Becker in 1949 (1). It most often appears in males of late childhood or young adolescence. Becker nevus is usually localized on upper trunk and arms. We herein present a 17 -year-old male with a $\mathrm{BN}$ on his ankle, a rare localization.

A 17-year-old boy referred to our department for an asymptomatic color change on his left ankle. He noted that the lesion first appeared 3 years ago and has been progressively extending and darkening since then. Dermatological examination revealed a $15 \times 10 \mathrm{~cm}$, brown patch with a geographic, well-defined border on the lateral aspect of his left ankle. Hypertrichosis wasn't seen on the patch (Figure 1a).

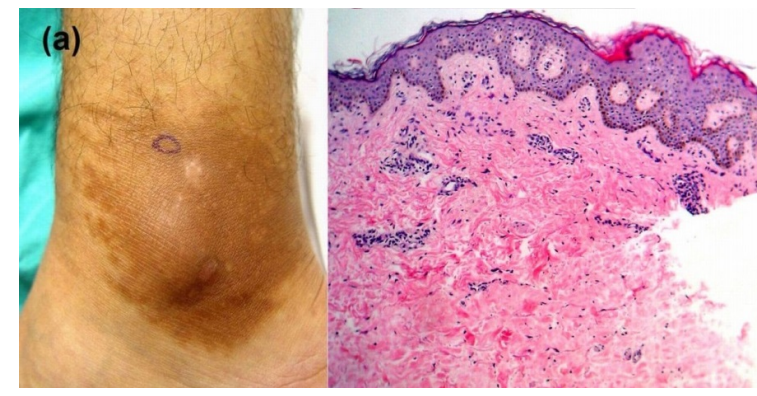

Figure 1. Well-defined brown patch without hypertrichosis on left ankle (a), Mild hyperkeratosis, papillomatosis, and basal hyperpigmentation in the epidermis; the bottom of some of the rete ridges was straight (b).

He denied any trauma or excessive sun exposure, or preceding inflammation in the area. The patient's past medical history was nonsignificant and his family had no history of similar disorders. General physical examination was normal and routine laboratory parameters were within normal limits. Histopathological examination revealed mild acanthosis and basal hyperpigmentation in the epidermis; the bottom of some of the rete ridges was straight (Figure 1b). Becker nevus diagnosis was made in the light of clinical and histopathological findings. Direct radiography and MR imaging of left ankle didn't reveal any alterations for bones and soft tissue.

Becker nevus is a common disorder with various clinical presentations. It has been described as single or multiple, unilateral or bilateral, syndromic or nonsyndromic. Hypertrichosis may accompany or not. The nevus can occur in all races, usually before the age of 15 (2). It is five times more seen in males than in females (3). The lesions mostly involve shoulders, upper chest, and scapular region; less frequently face, neck, and extremities (2). Lower extremity involvement is seen in only $3 \%$ of patients with BN (4). All of the lower extremity $\mathrm{BN}$ that had been reported in the literature was located above the knee except two cases. One of these involved the right lower abdomen, thigh, entire leg and genitalia (5). In this patient, BN was accompanied with lichen planus. The other case had multiple BN involving bilateral pretibial areas (6).

Becker nevus might be confused mainly with café-au-lait macules. Café-au-lait macules are often present at birth or appear shortly thereafter, have an oval morphology with welldefined and regular margins than geographical outline, are completely macular on sidelighting, and aren't hairy. 
To our knowledge, this is the first case of BN with isolated below-knee localization as a single lesion. The reason why $\mathrm{BN}$ is reported less frequently in lower extremities may be that lower limbs are cosmetically more negligible sites than trunk and upper extremities.

\section{REFERENCES}

1. Becker SW. Concurrent melanosis and hypertrichosis in distribution of nevus unius lateris. Arch Derm Syphilol 1949; 60: 155-60.

2. Ortonne JP, Bahadoran P, Fitzpatrick TB, Mosher $D B$, Hori Y: Hypomelanoses and Hypermelanoses, In: Freedberg IM, Eisen AZ, Wolff K, Austen KF, Goldsmith LA, Katz SI (Eds): Fitzpatrick's Dermatology in General Medicine. 6th edition, New York, McGraw-Hill, USA 2003:836-80.

3. Happle R, Koopman RJJ. Becker nevus syndrome. Am J Med Genetics 1997; 68: 357-61.

4. Tymen R, Forestier J-F, Boutet B, Colomb D. Naevus tardif de Becker: A propos d'une serie de 100 observations. Ann Dermatol Venereol 1981; 108: 41-6.

5. Terheyden P, Hornschuh B, Karl S, Becker JC, Bröcker EB. Lichen planus associated with Becker's nevus. J Am Acad Dermatol 1998; 38: 77072.

6. Schepis $C$, Lentini $M$, Failla $P$, Castiglia L, Fichera $\mathrm{M}$, Romano $\mathrm{C}$. An unusual presentation of Becker Nevus. Eur J Dermatol 2010; 20: 522-3. 